\section{The Blue Counterrevolution} The First Year of President Viktor Yanukovych

Yevgen Sautin

University of Florida, History and Economics, Class of 2012

The initial 100 days of Viktor Yanukovych's presidency appeared to be a complete departure from the Yushchenko presidency. While publicly reiterating his commitment to integration with the European Union and supporting transparency, freedom of the press, and democracy, Yanukovich has also seemingly positioned Ukraine firmly under Russia's orbit. Viktor Yanukovich's authoritarian tendencies combined with a sudden tilt towards Russia have galvanized the divided opposition, which has accused Yanukovich of outright treason. Amid all the fears of being a puppet of the Kremlin, Yanukovych has already voiced opposition to the most audacious Russian projects for greater partnership, and relations with Russia are bound to cool off once the initial honeymoon comes to an end. Furthermore, Yanukovich has not abandoned Ukraine's ties to the United States and the E.U., for he needs their support if he is to succeed in fixing Ukraine's economy and remain on equal footing with Russia.

Viktor Yanukovych's first year as Russian envelopment are mostly unfounded. President of Ukraine has been tantamount Indeed, international attention solely on to a counterrevolution. His initial actions Ukrainian foreign policy has resulted in many have been almost complete departures losing focus on the broader aims of Viktor from the policies of his predecessor, Viktor Yanukovych. With each passing month it Yushchenko, who led the Orange Revolution becomes clearer that Viktor Yanukovych is not in 2004. Yanukovych has effectively ignored a second Dmitry Medvedev out to do Vladimir his campaign pledges of fixing the economy, Putin's bidding; he is becoming ever more raising quality of life and taming corruption, like Alexander Lukashenka, the President of but instead has focused on building a strong Belarus widely dubbed "the last dictator in partnership with Russia. The sudden reversal Europe." It is a telling sign of Yanukovych's of course has caught the West off-guard intentions that the Constitutional Court has seeing as most have predicted Yanukovych to ruled that the hallmark reform legislation be considerably less pro-Russian since his loss of the Orange Revolution-the curbing of in 2004. ${ }^{1}$ Even though Yanukovych has lost presidential powers- is unconstitutional. ${ }^{2}$ little time in moving closer towards Russia, he has already rebuked several of the more ambitious Russian efforts to bring Ukraine into its orbit. In fact, it is highly unlikely that warm relations with Russia will persist throughout his first term. Tensions have already mounted over the energy agreements between the two countries-agreements that are at the heart of Russo-Ukrainian relations.

The refusal of Yanukovych and his Prime Minister, Mykola Azarov, to merge the Ukrainian owned Naftogaz with Russian owned Gazprom show that Western fears of branch has little prospect for success. Hence, Yanukovych's team has wasted little time in strengthening the Party of Regions' (the President's party) grasp of power in regional and municipal governments while attacking the already fractured opposition. A slew

Even though Yanukovych has lost little time in moving closer towards Russia, he has already rebuked several of the more ambitious Russian efforts to bring Ukraine into its orbit.

of legal changes made it more difficult for opposition parties to unite and register for the recent fall regional elections. ${ }^{5}$ In addition, NGOs and the press have felt crackdowns. The staunchly pro-Western Channel 5 has lost its broadcasting rights while the proYanukovych Inter channel has seen its media share balloon. ${ }^{6}$ More portentous are the reports of opposition politicians being investigated by the Ukrainian security services and threatened with prosecution. ${ }^{7}$ Due to the sensational nature of Ukrainian politics, it is hard to determine if there is any evidence to these claims. While it may be unlikely that the self-proclaimed leader of the opposition, Yulia Tymoshenko, is in any danger of a politically motivated arrest, several business rivals of Yanukovych's team have faced pressure from the SBU, the Ukrainian successor organization to the KGB. ${ }^{8}$

Yanukovych's detractors enjoy poking fun at his frequent gaffes, and portray him as a man of limited mental abilities, going as far as to label him a "vegetable." 9 He may not know how to spell the word professor (he wrote in "proffesor" for his occupation on an election qualifying form $)^{10}$, but he has succeeded where none have previously, by taming a traditionally rambunctious political milieu. Ukraine's nineteen years of independence have been defined by constantly reoccurring protests and snap elections, as one coalition after another ceased to function. ${ }^{11}$ It is a testament to the success of the Party of Regions that the opposition has been relegated to publicity stunts like the one seen during the ratification of the Kharkiv agreement. ${ }^{12}$ The opposition is powerless to stop legislation in the parliament, called the Verkhovna Rada, because the ruling coalition has unconstitutionally poached individual members of parliament to swell its ranks ${ }^{13}$; thus enabling it to bypass opposition parliamentary delaying tactics. Moreover, the Party of Regions has made gains in the regional elections held on October $31 \mathrm{st}$,

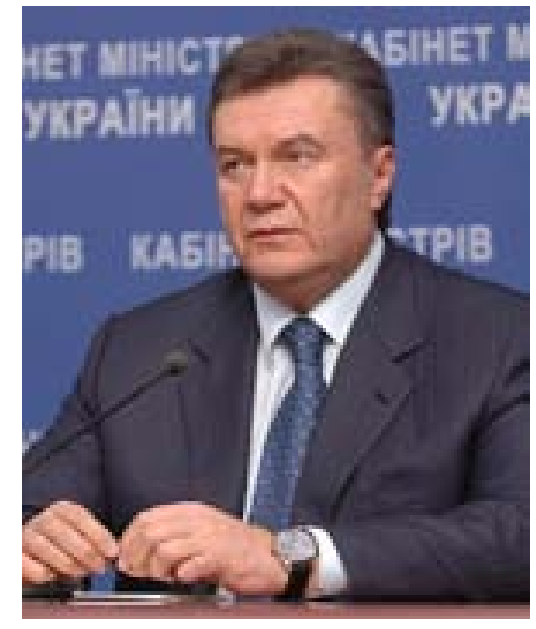

Ukrainian President Viktor Yanukovych

further cementing its hold on power.

Considerable emphasis has been put on the upcoming Euro 2012 soccer tournament. The right to cohost the tournament with Poland was considered a major Viktory for Viktor Yushchenko in 2007 when the decision was announced. Since then, Ukraine has faced questions regarding the readiness of the country to host the tournament. ${ }^{14}$ Fears mounted that the bid would be given instead to either Hungry or Germany ${ }^{15}$, and in response Yanukovych pledged to ensure that the tournament will go as planned. To that end, Ukraine has witnessed unprecedented improvements to its airports, roads and hotels, many of which have not seen major improvements since the collapse of the Soviet Union. ${ }^{16}$ The tournament serves the 
dual purpose of uniting the entire populace being the pro-business candidate, Yanukovych while giving Yanukovych the opportunity to needs to turn around the economy if he

further showcase his accomplishments both is to remain in power. Ukraine's economy in the domestic and the foreign arena.

The Euro 2012 is the most visible example of Yanukovych's aim to portray

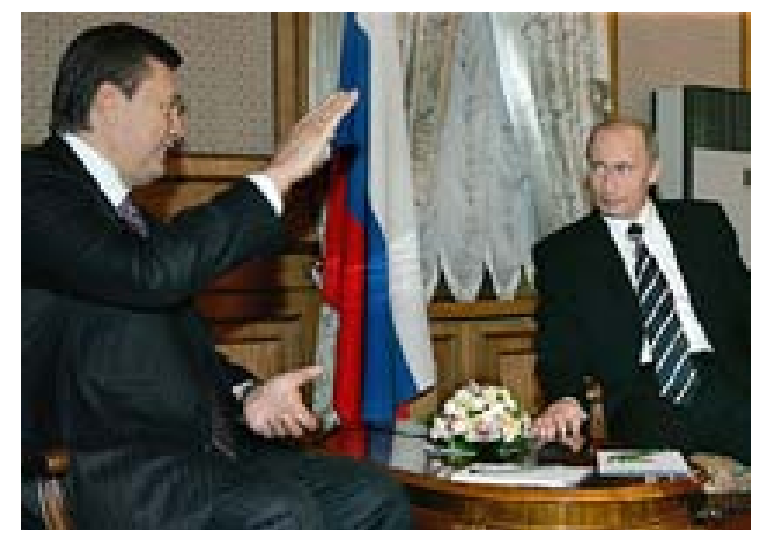

Viktor Yanukovych meets with Russian President Validimir Putin

himself as a tough, can-do modernizer who is also of the people. His $60^{\text {th }}$ birthday was honored by a major TV station with a sixty minute sycophantic tribute that resembled the minor cults of personalities that have emerged in Central Asian states. ${ }^{17}$ Such publicity campaigns seek to hide the fact that Yanukovych is a man deeply fearfu for his life; he lives in a heavily guarded compound outside the city, traveling daily in a long cortege of bulletproof cars that hold up traffic for hours. ${ }^{18} \mathrm{He}$ has also surrounded himself with loyal Donetsk cronies that are given exclusive rights to all the government contracts, such as the Euro 2012 tenders. The head of the SBU, Valerii Khoroshkovskiy, is married to the chief shareholder of the Inter media conglomerate mentioned earlier and is also a key player in UkrTransGas - a murky third party at the heart of the European natura gas market. ${ }^{19}$ Yanukovych and his team are using the presidential office as a means to place themselves and their oligarch backers at the top of the Ukrainian economy.

Although he has secured the political front, Yanukovych's Achilles's heel is the economy. Running under the auspices of contracted by 15.1 percent last year and was on the verge of a default. Most of the steel and heavy machinery industries that make up the bulk of the Ukrainian industry are uncompetitive and rely on subsidized gas prices. The gas deal with Russia should somewhat help prop up the industries, but it also places caps on the amount of gas that can be bought at discounted rates; after 30 billion cubic meters the price returns to market levels. ${ }^{20}$ The energy agreement also does not shield the average consumer; utility rates increased by $50 \%$ over the summer, in part to satisfy criteria for the $\$ 15$ billion dollar IMF loan. Azarov has publicly stated that he wished to negotiate an additional agreement with Russia to lower the consumer price but such an agreement would entail the merger of Gazprom and Naftogaz, something that Yanukovych has so far opposed. ${ }^{21}$

For all the talk of economic reform and combating corruption, Yanukovych has offered few ideas on how to make good living. He is heavily reliant on the support of oligarchs, whose primary interests are access to subsidized natural gas for heavy industries and easy credit. So crucial is the access to easy credit for the likes of Roman Akhmetov and Dmytro Firtash that the oligarchs voiced their displeasure at Yanukovych for failing to secure a loan from Russia and called on him to get one from the IMF. ${ }^{22}$ The IMF loan comes with conditions that are already hurting the average Ukrainian, but Yanukovych is not about to alienate his chief source of support. ${ }^{23}$ The example underscores his chief weakness: Yanukovych can go about limiting press freedoms and cementing his grip on power only if the economy performs well enough to placate the weary populace. If the economic situation does not improve, his heavy-handed tactics will not keep the opposition at bay indefinitely. on his promise to improve the standard of

\section{Relations with Russia: A}

Brotherly Union! ${ }^{24}$

As stated earlier, repairing relations with Russia has been at the cornerstone of Ukrainian foreign policy since Yanukovych assumed office as president. Yanukovych's firs action as president and his most significant to date was the Kharkiv agreement ${ }^{25}$. Under the deal, Ukraine would receive a discount on gas prices in exchange for the right to use Crimea as a base for the Russian Black Sea Fleet until at least 2042. The agreement was reached virtually overnight and hastily ratified in the Rada amid fistfights on the floor, smoke grenades, the egging of the Rada speaker and the draping of a huge Ukrainian flag over the seats of the opposition; giving the entire proceeding a very phantasmagorical feel. ${ }^{26}$ Since then the two countries have embarked on a dizzying spree of signing ceremonies and mutual pledges in almost every imaginable sphere. There are talks of unifying the aerospace $\mathrm{e}^{27}$ and naval industries ${ }^{28}$ to make them more competitive on the world market; cooperation on nuclear energy ${ }^{29}$; the writing of a joint history textbook ${ }^{30}$, a prospect far more controversial than one might think there is speculation that the various Orthodox churches in Ukraine will unify under the Moscow patriarch ${ }^{31}$; there are even rumors circulating that a secret agreement over the fate of neighboring Moldova was signed earlier this year. ${ }^{32}$ For all the pomp and circumstance and public reaffirmations of "brotherly" bonds, there has been no real push to make any of the aforementioned plans a reality. If the later rumor is almost certainly nothing more than an opposition fabrication to stir up fear even the supposedly serious proposals of an aeronautical consortium have stalled.

Viktor Yanukovych needs cheap Russian gas to prop up the country's economy and the industries of his oligarch supporters, he also needs good relations with Russia to keep his pro-Russian electorate happy. The later goal can be achieved with domestic policies such as institutionalizing Russian as a second official language ${ }^{33}$, or removing the Yushchenko era changes to the school curriculum that glorified Nazi collaborators as Ukrainian freedom fighters. In turn, this means that Yanukovych has no personal need for greater integration with Russia. Any sort of economic, social or especially political, integration would threaten his autonomy and interests. This can be seen by his adamant refusal for a merger between Gazprom and Naftogaz. ${ }^{34}$

All of this points to a relationship that will not stand the test of time. In fact, there are signs that the honeymoon period is already over. Ukrainian oligarchs are disappointed with the terms of the gas agreement and there are calls for a renegotiation on the price. So far Vladimir Putin has stated that Russia has already paid 'too high a price' for the Russian Black Sea Fleet and has given Ukraine generous gas subsidies. ${ }^{35}$ Russia wishes to acquire Naftogaz or at the very least secure the transit infrastructure in Ukraine. Yanukovych has

Victor Yanukovych needs cheap Russian gas to prop up the country's economy and the industries of his oligarch supporters, he also needs good relations with Russia to keep his pro-Russian electorate happy.

called against such an acquisition and is only willing to entertain talks of a merger based on equal terms. ${ }^{36}$ Ukraine is also seeking direct ownership of natural gas mining sites along with investment for infrastructure improvement. ${ }^{37}$ In particular, Yanukovych is seeking Western assistance in modernizing the country's gas infrastructure, something Moscow opposes.

Ukraine has made no effort to move forward on talks of consolidating the naval or aeronautical industries and even talks 
of nuclear energy cooperation have so far yielded scant results. ${ }^{38}$ All three industries were to form consortiums that were to improve the competitiveness of the respected firms on the world market. Ukraine is willing to sign an aeronautical consortium only on terms that benefit its Antonov factory and that would allow Ukraine to get cheaper parts from Russia; it is not actually interested in forming a new jointly owned corporation. It is even less open to any sort of naval building agreement. With nuclear energy cooperation there has been more progress since it is under the general umbrella of crucial energy talks: Russia is to build a new plant in Ukraine to process uranium in exchange for becoming the sole provider of nuclear fuel for Ukrainian reactors. ${ }^{39}$ The later point has been a bone of contention and it is unclear at this time if the talks will bear fruit.

In terms of broader geopolitical alignment, the decision to continue to sell arms to Georgia ${ }^{40}$ and the agreement to ship Venezuelan oil to Belarus ${ }^{41}$, clearly show that Yanukovych does not plan on being a puppet of the Kremlin. Ukraine has so far refused to recognize either South Ossetia or Abkhazia ${ }^{42}$ and has publicly reiterated that it has no intentions of joining the Collective Security Treaty Organization (CSTO) ${ }^{43}$. Ukraine has also voiced concerns regarding Russia's plans of building the South Stream gas pipeline that would bypass Ukraine and reduce its transit clout. ${ }^{44}$ Heretofore, Vladimir Putin's visits to Yanukovych's Ukraine have been occasions of great pomp and circumstance and have resulted in ambitious albeit platitudinous agreements; it is a telling sign that his last visit amounted to little more than a signing of previously reached agreements in a much more subdued atmosphere. ${ }^{45}$

\section{Relations with the West: Onwards}

\section{to a Bright Future! ${ }^{46}$}

Despite Viktor Yanukovych's proRussian stance, prospects for cooperation between the E.U. the United States and
Ukraine has not significantly deteriorated from the Yushchenko administration. With the prominent exception of NATO membership, which will almost certainly not occur in the foreseeable future, much of the rhetoric of the Yushchenko administration has carried over to the new administration. Simply put, Ukraine needs the west. Ukrainian energy infrastructure, including natural gas pipelines, is in dire need of modernization and repairs. Since any assistance from Moscow would come under the condition of greater control of the Ukrainian energy sector, the Ukrainian government has publicly called for western investment in the natural gas infrastructure. ${ }^{47}$ The prospect of E.U. involvement in energy infrastructure modernization greatly angers Moscow, which wishes to further its control over the transit system. ${ }^{48}$ Cooperation on this matter will serve as a check on Russian influence while simultaneously allowing the E.U. to prod Yanukovych on domestic matters if it so chooses.

Yanukovych has said that, "Ukraine's future is in Europe," and officially E.U. membership remains the ultimate goal for Ukraine. ${ }^{49}$ The Ukrainian foreign ministry has lobbied hard albeit with little success, for an abolishment of visa regulations with the E.U. or at the very least an ease in the regulations. ${ }^{50}$ Ukraine is also actively seeking an Associate Member status within the E.U. ${ }^{51}$ For all the talk of integrating Ukraine with Europe, Viktor Yushchenko had actually done fairly little to that end. Ukraine has recently signed a free trade agreement with the European Free Trade Association (EFTA) and was eager to accept the latest IMF loan to avoid approaching the Russians for financial assistance. While Yanukovych himself may have little interest or incentive in joining the E.U., he understands that the vast majority of his people have an inexorable yearning to become a member state. $^{52}$ Ukrainians believe E.U. membership would improve the economy, reduce corruption, reintegrate Ukraine with Europe, and improve its security and prestige. ${ }^{53}$ Hence,
Yanukovych has to at least pay lip service to those sentiments and continue to be seen as supportive of integration.

In an obvious effort to reach out, Yanukovych gave up the remaining Ukrainian highly enriched uranium during his visit to the United States ${ }^{54}$ and has allowed military exercises to be held with NATO. The later move was sharply criticized in the Russian press and is evidence that Yanukovych intends to keep his options open..$^{55}$ The Yanukovych administration has shown willingness to challenge E.U. member states on policy differences as can be seen by their efforts to halt Romanian economic encroachment along the Danube delta. ${ }^{56}$ Under the previous administration, the Ukrainian government had an obsequious policy of not challenging E.U. member states on anything. ${ }^{57}$ While the

\section{Endnotes}

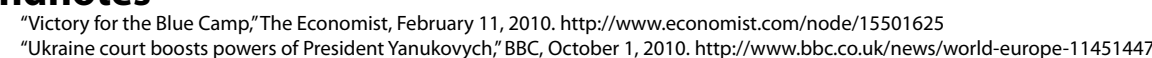

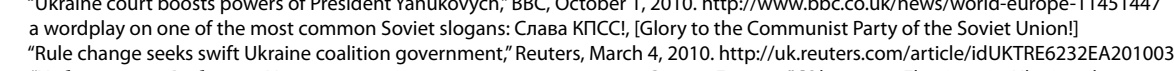

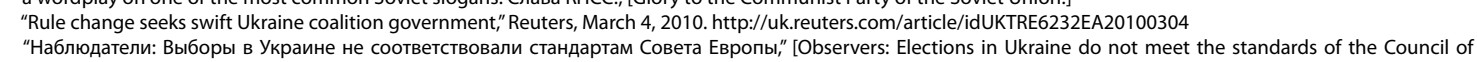
Uuropel, Korrespondent, November 2, 2010. http://korrespondent.net/ukraine/politics/1133615-nabl/Wy evropy

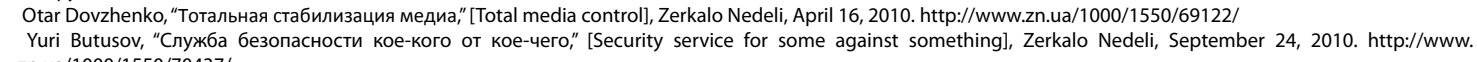

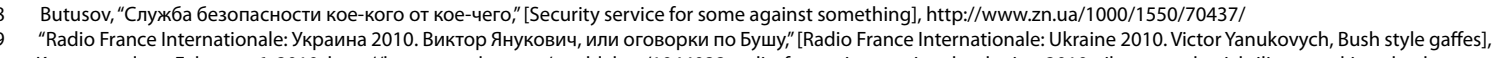

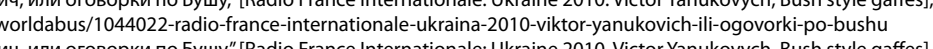
http://korrespondentnet/wordabus 1044022 -radio-france-internationale-ukraina-2010-viktor-yanukovich-ili-ogovorki-po-bushu Kubick, Paul. 2007. "Ukraine and the European Neighborhood Policy: Can the EU Help the Orange Revolution Bear Fruit?" "East European Quarterly 41, no. 1: 1-23.

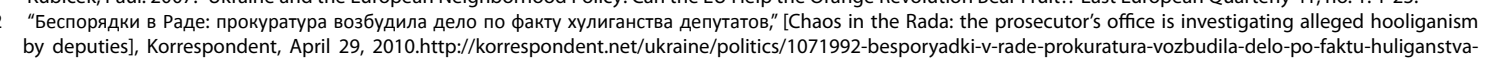
deputatov

13
"Rule change seeks swift Ukratere

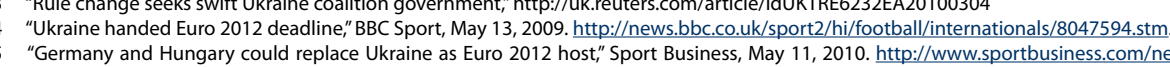

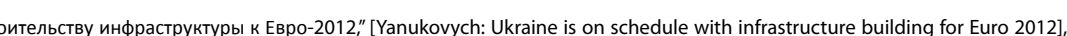
Korrespondent, November 3, 2010, http://korrespondent.net//euro/1 134184-yanukovich-ukraina-voshla-v-grafik-po-stroitelstsu-inffrastruktury-k-evro-2012

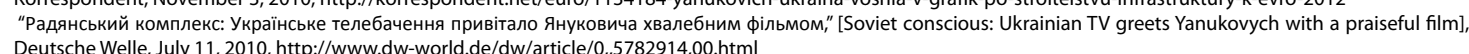

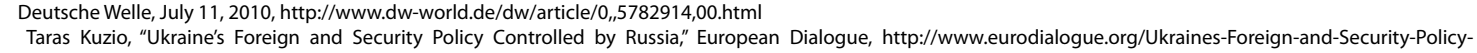
Controlled-by-Russia

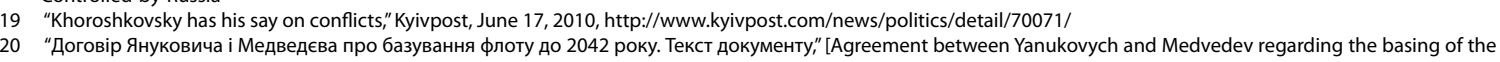

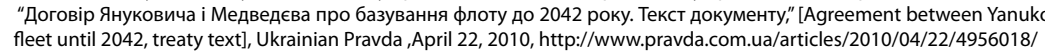

"Ukraine to renegotiate 'unfair' gas deal with Russia," EurActiv, OCtober 18 2010

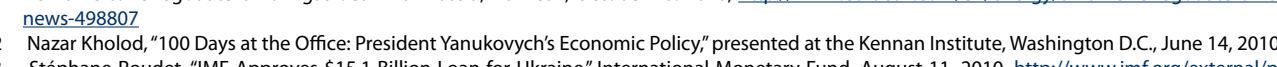

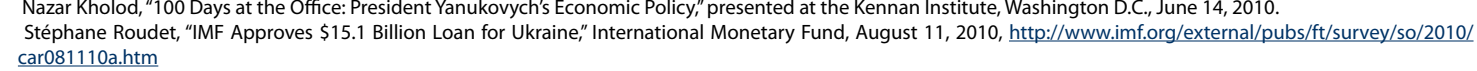

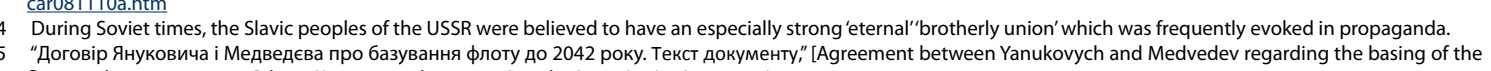
fleet until 2042, treaty text], http://www.pravda.com.ua/articles/2010/04/22/4956018/

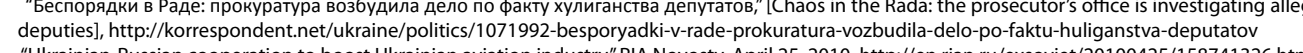

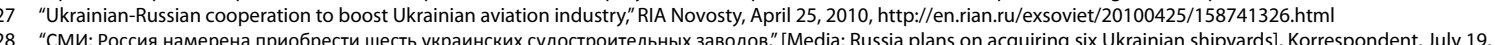
2009, http://korrespondent.net/business//economics/1097769-smi-rossiya-namerenana-priobresti-shest-ukrainskih-suddostroitelenyh-zavodov

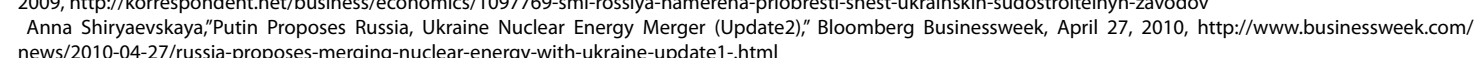

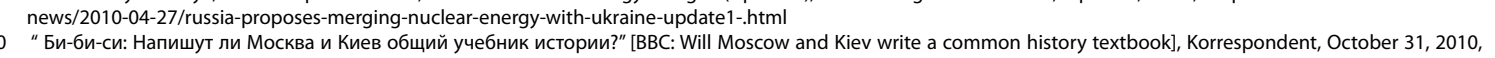


Publications Associates

Athena Diaconis ' 11

Jacob Baker '11

\section{Global Networking Staff}

Ari Hyman '14

Alexander Cooper '14

Colin Murphy ' 11

Luke Namer '13

Kristen Archibald ' 13

Tareq Ali '13

Dhairyasheel Ghodalkar '14

(a)

\section{News Digest Staff Writers}

James Rockas '12

Joseph Anderson '12

Alex Heikali '13

Colin Murphy ' 11

Dan Cahalane' 12

Ryan Navi '13

Dhairyasheel Ghodalkar '14

Alexander Cooper '14

Kristen Archibald '13

Kirat Singh '14

Luke Namer '13

Aaron Schifrin '14

Submission Guidelines

Please send submissions to President.CIAR@gmail.com or in hard copy at 401 Willard Straight Hall, Ithaca, NY 14850

Submissions should be approximately $\mathbf{3 0 0 0}$ words, but upon discussion with the editors, the limit may be reduced or expanded. Writers are encouraged to look at the articles published in previous issues to get acquainted with the style of CIAR. Submissions should be accompanied by a short biography of the author.

Articles that fit the criteria will be presented to the Editorial Board and reviewed. The Board will inform the author of its decision once their review process is over. The editing process then starts, with a series of back-and-forth between the assigned editor and the author. The Board reserves the right to make some minor changes before publication.

\section{How to make your contribution to CIAR}

In order to make a donation to our organization, you can visit Cornell University's Give to Cornell website (www.giving.cornell.edu). There, select option to give online under the designation of "Cornell University - Other". In the description, please specify that the gift is going to the Cornell International Affairs Review. If you would like assistance in planning your gift or preparing the paperwork for tax credit, you can also contact the Office of Trusts, Estates and Gift Planning (gift_planning@cornell.edu or 1 (800) 481-1865) and they can guide you through the process.

\section{Contributors}

The Mario Einaudi Center for International Studies, International Student Programming Board, Student Assembly Finance Commission, Cornell Institute for European Studies, Department of Government, The Lenquesaing Family, The Pedraza Family, Craig Yunker, Susan Kalus

News Digest Editors
Abdiel Ortiz-Carrasquillo '13
Erick Castillo Mares '13
Public Relations
Associates
Luke Namer '13
Alexa Bruer'13
Global Liasons
Erin Szulman '12
Sam Worby '12

We thank our contributors for their support. 